\title{
Kidney Cancer Pathology in the New Context of Targeted Therapy
}

\author{
Yves Allory ${ }^{a, b}$ Stéphane Culine ${ }^{a, c} \quad$ Alexandre de la Taille ${ }^{a, d}$ \\ aINSERM U955, Team 7 'Translational research in genitourinary oncogenesis', and Departments of \\ ${ }^{b}$ Pathology, 'Medical Oncology, and dUrology, Henri Mondor Hospital, AP-HP, Créteil, France
}

\section{Key Words}

Renal cell carcinoma $\cdot$ Targeted therapy $\cdot \mathrm{VHL} \cdot \mathrm{HIF} \cdot \mathrm{VEGF}$. mTOR

\begin{abstract}
The outcome in metastatic renal cancer remains poor with an overall survival at 5 years of less than $10 \%$. However, molecular pathology in kidney cancer has developed extensively in the few last years, providing a basis for new systemic therapies including antiangiogenic drugs and mTOR inhibitors. Use of these targeted therapies in metastatic disease has improved the prognosis but still in a too-limited range, with a lack of consistent predictive biomarkers. The multiple entities of renal tumors add complexity to the research of biomarkers and the design of clinical trials. This review aims to focus on pathways in renal cancer (VHL/HIF, mTOR, c-MYC, c-MET, and immune response) in the respective tumor subtypes, accounting for the effects of targeted therapies and providing the framework to search for relevant predictive biomarkers and propose new trials. This overview underscores that the pathways are often intermingled and common (at least partially) to the different tumor subtypes.
\end{abstract}

Copyright ๑ 2011 S. Karger AG, Basel

\section{Introduction}

Renal cell carcinoma (RCC) accounts for $2-3 \%$ of all malignant diseases in adults [1]. The incidence of all stages of this cancer has increased over the last 20 years, contributing to an increasing mortality rate. Twenty to $30 \%$ present with metastasis and $20-30 \%$ relapse after curative nephrectomy. The overall 5-year survival ranges from $85 \%$ for patients with organ-confined disease treated with partial or radical nephrectomy to only $10 \%$ in patients with metastatic disease or relapse after nephrectomy [2]. Renal cancer is not one entity but rather a collection of different types of tumors (clear cell, papillary, and chromophobe cell types being the most frequent), each derived from various parts of the nephron, with morphological and genetic features (WHO 2004 classification and emerging entities likely to be included in future WHO classifications; table 1) [3]. Molecular pathology in kidney cancer has developed extensively in the few last years providing insights into the underlying oncogenesis with a new basis for accurate classifications and more effective systemic therapy. However, in renal cancer, the use of targeted therapies in metastatic disease still lacks consistent predictive biomarkers [4]. This review

\section{KARGER \\ Fax +4161306 1234 \\ E-Mail karger@karger.ch}

www.karger.com
(C) 2011 S. Karger AG, Basel

1015-2008/11/0782-0090\$38.00/0

Accessible online at:

www.karger.com/pat
Yves Allory

Department of Pathology, Henri Mondor Hospital

51, av. Mal-de-Lattre-de-Tassigny

FR-94010 Créteil Cedex (France)

Tel. +33 1498127 29, E-Mail yves.allory@hmn.aphp.fr 
Table 1. RCC classification: WHO 2004 classification and emerging entities

\begin{tabular}{|c|c|}
\hline Tumor type & Main recurrent genetic changes \\
\hline $\begin{array}{l}\text { WHO } 2004 \\
\text { Clear cell RCC }\end{array}$ & 3p25 VHL, 3p21 RASSF1A, 3p14.2 FHIT: deletion, mutation, methylation \\
\hline Multilocular cystic RCC & 3p25 VHL: mutation \\
\hline Papillary RCC & Trisomy 7, 17; gain 7q31 c-MET; Y loss \\
\hline Chromophobe RCC & $1,2,6,10,13,17,21$, Y multiple chromosome loss \\
\hline Collecting duct carcinoma & Monosomy $1,6,14,15,22$ (based on a few cases) \\
\hline Renal medullary carcinoma & No gain or loss on CGH (based on a few cases) \\
\hline RCC associated with Xp11.2 translocation & $\begin{array}{l}\text { Translocation PSF-TFE3 } \mathrm{t}(\mathrm{X} ; 1)(\mathrm{p} 11.2 ; \mathrm{p} 34), \text { PRCC-TFE3 } \mathrm{t}(\mathrm{X} ; 1)(\mathrm{p} 11.2 ; \mathrm{q} 21) \text {, } \\
\text { CLTC-TFE3 } \mathrm{t}(\mathrm{X} ; 17)(\mathrm{p} 11.2 ; \mathrm{q} 23), \text { ASPL-TFE3 } \mathrm{t}(\mathrm{X} ; 17)(\mathrm{p} 11.2 ; \mathrm{q} 25) \text {, ? } \mathrm{t}(\mathrm{X} ; 3)(\mathrm{p} 11.2 ; \mathrm{q} 12) \text {, } \\
\text { or NonO-TFE3 inv }(\mathrm{X})(\mathrm{p} 11.2 ; \mathrm{q} 12)\end{array}$ \\
\hline Postneuroblastoma RCC & To be defined \\
\hline Mucinous tubular and spindle cell carcinoma & Multiple chromosome losses (based on a few cases) \\
\hline RCC unclassified & Not relevant \\
\hline $\begin{array}{l}\text { Emerging entities } \\
\text { RCC associated with } 6 \text { p } 21 \text { translocation }\end{array}$ & Translocation Alpha-TFEB t $(6 ; 1)(\mathrm{p} 21 ; \mathrm{q} 12)$ \\
\hline Tubulocystic carcinoma & Trisomy 7,17 ; Y loss \\
\hline Acquired cystic disease-associated RCC & To be defined \\
\hline Clear cell papillary RCC & To be defined \\
\hline Thyroid-like follicular carcinoma & To be defined \\
\hline Oncocytic papillary RCC & Trisomy 7, 17; Y loss (based on a few cases) \\
\hline Leiomyomatous RCC & 3p25 VHL, 3p14.2 FHIT: deletion (based on a few cases) \\
\hline
\end{tabular}

$\mathrm{CGH}=$ Comparative genomic hybridization.

aims to focus on molecular profiles in renal cancer accounting for the effects of targeted therapies and substantiating the search for relevant predictive biomarkers.

\section{Classification and Clinical Trials}

Advanced disease is refractory to radiotherapy and known chemotherapies, and the only treatment available for metastatic disease has been, for a long time, immunotherapy based on interleukin (IL)-2 and/or interferon (IFN)- $\alpha$, with a lasting response in less than $10 \%$ of patients. In the 2000s, a new paradigm has emerged in renal cancer with the use of effective targeted therapies, including antiangiogenic agents (anti-VEGF A antibody bevacizumab and VEGFR2 tyrosine kinase inhibitors sunitinib and sorafenib) and mammalian targets of rapamycin (mTOR) inhibitors (temsirolimus and everolimus). Most of these drugs are currently used as first-line treatment in metastatic disease (see current recommenda-

Kidney Cancer Pathology in the Context of Targeted Therapy tions; table 2). A comparison of overexpressed genes in the 3 most frequent subtypes of renal cell carcinoma showed both common and specific sets of genes between clear cell, papillary, and chromophobe cell carcinomas, suggesting the potential importance of tumor subtyping when investigating biomarkers and targeted therapies [5]. Thus, the beneficial effects of VEGFR inhibitors sunitinib and sorafenib have been demonstrated for patients with clear cell RCC in distinct settings (table 2), and they appear more limited in patients with papillary or chromophobe cell RCC [6]. Conversely, the temsirolimus regimen seems to demonstrate a more significant effect on median survival in patients with non-clear cell RCC (including $75 \%$ of papillary RCC) than in patients with clear cell RCC [7]. Clinical trials are currently recruiting patients to assess the precise effect of mTOR inhibitors on metastatic papillary RCC.

Meanwhile, the pathological classification of renal cancer has been significantly extended with the description of new entities based on histological and/or molecu- 
Table 2. Targeted therapy in renal cancer: standard recommendations 2010

\begin{tabular}{|c|c|c|c|c|}
\hline Setting & Tumor subtype & Context $^{1}$ & First choice (evidence of phase III) & Alternative \\
\hline $\begin{array}{l}\text { First-line } \\
\text { therapy }\end{array}$ & $\begin{array}{l}\mathrm{CC} \\
\mathrm{CC} \\
\mathrm{NCC}(\mathrm{PAP})\end{array}$ & $\begin{array}{l}\text { Good or intermediate risk } \\
\text { Poor risk } \\
\text { All risks }\end{array}$ & $\begin{array}{l}\text { Sunitinib or bevacizumab + interferon } \\
\text { Temsirolimus } \\
\text { New drugs tested in clinical trials }\end{array}$ & $\begin{array}{l}\text { High-dose IL-2 } \\
\text { Sunitinib }\end{array}$ \\
\hline $\begin{array}{l}\text { Second-line } \\
\text { therapy }\end{array}$ & $\begin{array}{l}\mathrm{CC} \\
\mathrm{CC} \\
\mathrm{CC} / \mathrm{NCC}\end{array}$ & $\begin{array}{l}\text { Prior cytokine } \\
\text { Prior VEGFR inhibitor } \\
\text { Prior mTOR inhibitor }\end{array}$ & $\begin{array}{l}\text { Sorafenib } \\
\text { Everolimus } \\
\text { New drugs tested in clinical trials }\end{array}$ & $\begin{array}{l}\text { Sunitinib } \\
\text { New drugs tested in clinical trials } \\
\text { New drugs tested in clinical trials }\end{array}$ \\
\hline
\end{tabular}

CC $=$ Clear cell; NCC (PAP) = non-clear cell (in particular, papillary carcinoma).

${ }^{1}$ Risk according to MSKCC risk status [58].

Table 3. Major hereditary forms of renal cancers

\begin{tabular}{llll}
\hline Syndrome & $\begin{array}{l}\text { Chromosome } \\
\text { location }\end{array}$ & Gene & $\begin{array}{l}\text { Associated renal tumor } \\
\text { subtype }\end{array}$ \\
\hline Von Hippel-Lindau & $3 \mathrm{p} 25$ & VHL & Clear cell RCC \\
\hline Hereditary papillary RCC & $7 \mathrm{q} 31$ & $c-M E T$ & Papillary RCC (type I) \\
\hline Hereditary leimyomatosis and RCC & $1 \mathrm{q} 42$ & $F H$ & Papillary RCC (type II) \\
\hline $\begin{array}{l}\text { Birt-Hogg-Dubé } \\
\text { Familial RCC associated with } \\
\text { constitutional chromosome 3 translocation }\end{array}$ & $17 \mathrm{p} 11$ & FLCN & $\begin{array}{l}\text { Oncocytoma, chromophobe RCC, hybrid oncocytic tumor } \\
\text { (less frequently, clear cell or papillary RCC) }\end{array}$ \\
\hline
\end{tabular}

All of these hereditary forms are associated with autosomal dominant inheritance.

$V H L=$ von Hippel Lindau, $c-M E T=$ hepatocyte growth factor, $F H=$ fumarate hydratase, $F L C N=$ folliculin.

lar criteria (table 1) [3]. The diagnostic features of the new entities have been reviewed recently [8]. It is important to note that some cases previously considered to be clear cell carcinoma or papillary carcinoma should be diagnosed according to updated criteria, e.g. as carcinoma associated with translocation TEF3 or TFEB, papillary carcinoma with clear cell, or carcinoma associated with acquired multicystic disease. A fraction of the cases included in the clinical trials would now be reclassified into new entities, with a potential impact on the trial conclusions according to histological subtypes. Retrospective analysis of former trials on the basis of pathological reexamination and new prospective trials should be performed to more precisely determine the relevance of the available therapies according to the different subtypes and prognosis groups of tumors. Overall, the context of intense research for consistent biomarkers predictive of treat- ment response underscores the interest in providing an accurate pathological diagnosis based on morphological, immunohistochemical, and genetic features [10].

\section{Genetic Changes in Sporadic and Hereditary Renal Cancers}

The genetic studies in sporadic and hereditary forms of renal cancer have created a relevant framework to integrate renal cancer pathology in the era of targeted therapy, providing a rationale for the treatments and suggesting potential predictive biomarkers. The recurrent cytogenetic changes in sporadic forms support the distinction of the different subtypes of renal tumors identified historically on morphological examinations (table 1). A few key genes have been identified, in particular with the in- 
vestigation of hereditary kidney cancer syndromes which are rare clinical entities (2-3\% of all renal cancer cases), but they offer valuable insights into the pathogenesis of kidney cancer through identification of the underlying genetic mechanisms common to hereditary and sporadic forms of the disease. Four major hereditary forms of renal cancer have been related to the following genes: Von Hippel Lindau (VHL), Hepatocyte Growth Factor Receptor (cMET), Fumarate hydratase (FH), and Folliculin (FCLN) (table 3). Among them, the tumor suppressor gene VHL (3p25) is frequently inactivated by deletion, mutation, or promoter methylation in sporadic forms of clear cell carcinoma (up to $86 \%$ of cases), underscoring its pivotal role in this tumor subtype $[11,12]$. According to this, global gene expression analysis in clear cell RCC shows frequent inactive VHL and active hypoxia and VEGF pathways [13]. Interestingly, a recent genome-wide analysis of copy number changes and gene expression profiles shed light on the clear cell RCC subtype, showing that sporadic clear cell RCC without evidence of biallelic VHL inactivation falls into 2 groups, i.e. one group with genomic profiles that are much more similar to tumors with biallelic inactivation of VHL, and another group with genomic profiles highly dissimilar to the majority of clear cell RCC [14].

The oncogene $c-M E T(7 \mathrm{q} 31)$ is frequently gained and occasionally mutated (13\%) in sporadic papillary RCC (type 1). For the tumor suppressor gene $F H$, no mutations in sporadic RCC have been detected, but the FH pathway is frequently underexpressed in papillary RCC (types 1 and 2) [13]. Inactivating mutations of the gene FLCN have been detected in sporadic chromophobe cell RCC (11\%), suggesting a tumor suppressor role, at least for the chromophobe-subtype oncogenesis [15]. AKT-mTOR and cmyc also appear to be activated pathways in fractions of clear cell and high-grade papillary RCC [13]. These signaling pathway alterations, whether specific or not for the different tumor subtypes, provide prime targets for systemic therapy in advanced disease.

\section{VHL and Hypoxia-Inducible Factor Pathways}

The loss of VHL (resulting from the inactivation of both alleles) is a critical event in the pathogenesis of most clear cell RCC [12]. The consequences include effects on the hypoxia-inducible factor (HIF) and HIF-independent effects. HIF is a heterodimeric transcriptional factor associating HIF1 $\alpha$ (or HIF2 $\alpha$ ) with the partner HIF1 $\beta$. The VHL gene product is a component of an E3 ubiquitin li- gase complex that targets HIF $1 / 2 \alpha$ subunits for polyubiquitylation and proteasomal degradation [16]. This process is dependent on the hydroxylation of conserved proline residues on the $\alpha$ subunits of HIF $1 / 2 \alpha$ in the presence of oxygen. When oxygen levels are low, or VHL is inactivated, HIF1 $\alpha$ or HIF $2 \alpha$ accumulate, form a heterodimer with HIF1 $\beta$, and translocate into the nucleus to regulate specific targets through binding to the hypoxia-responsive elements located in the promoter/enhancer regions of hypoxia-inducible genes [17]. HIF1 $\alpha$ or HIF $2 \alpha$ share significant homology and regulate partially overlapping repertoires of hypoxia-inducible target genes but may have distinct effects on RCC cell growth $[18,19]$. HIF3 $\alpha$ is a third HIF $\alpha$ which probably acts as a dominant negative inhibiting the effects of HIF $1 \alpha$ and HIF $2 \alpha$. According to in vitro and in vivo models, stabilization of $\operatorname{HIF} 2 \alpha$, but not HIF $1 \alpha$, is the critical oncogenic event in the development of clear cell RCC, and clear cell carcinoma produces either HIF $1 \alpha$ and HIF $2 \alpha$ or HIF $2 \alpha$ alone. HIFresponsive gene products include genes involved in angiogenesis (VEGF, PDGF, SDF, CXCR4, TGF $\beta$, and CTGF), glucose uptake and metabolism (HK2 and PDK4), $\mathrm{pH}$ control (CAIX and CAXII), invasion/metastasis (MMP1, $S D F, C X C R 4$, and $c-M e t)$, proliferation, and survival $(T G F \alpha)$ [18]. This gene-program activation accounts for the prominent angiogenesis observed in clear cell carcinoma and the effects of targeted therapy directed at VEGF or VEGFR2 (the main VEGF receptor expressed in clear cell RCC, also called KDR). Bevacizumab is a recombinant human monoclonal antibody able to bind and neutralize VEGF, resulting in decreased angiogenesis [20]. Sunitinib is a small tyrosine kinase inhibitor of VEGFR2, PDGFR-B, FLT-3, and c-KIT and has an effect on both untreated metastatic RCC patients (median progression-free survival, 11 months) and cytokine refractory metastatic clear cell RCC patients (median progression free-survival, 8.8 months) [21, 22]. Sorafenib, another small kinase inhibitor, displays activity against VEGFR2, VEGFR3, PDGFR-B, FLT-3, c-KIT, and RAF-1, assumed to account for the prolongation of progressionfree survival observed both in previously untreated and cytokine refractory metastatic clear cell RCC patients $[1,23]$.

Available antiangiogenic therapy in the adjuvant setting for tumors at risk of progression after curative nephrectomy is under investigation. Moreover, almost all kidney cancer patients treated with VEGF inhibitors experience disease progression, and further strategies should include attempts to identify a new gene/pathway addiction created in cells defective for VHL protein func- 
tion as well as to inhibit compensatory mechanisms that promote tumor survival in the setting of VEGF pathway blockade. Interestingly, the HIF-independent effects of VHL loss remain poorly understood but could involve activation of the NFKB pathway promoting survival, in particular with the removed inhibition of the NFкB agonist Card9 [24]. A recent study also pointed at the consequences of VHL loss in mitotic spindle disorientation and the promotion of genetic instability [25].

Another current issue is the validation of tumor biomarkers predictive of the response to antiangiogenic therapy. Recent studies have proposed clinical (time from diagnosis to VEGF-targeted therapy $<2$ years, 2 or more metastatic sites, and ECOG PS $>0$ ) and biological (neutrophils $>4.5 \times 10^{3} / \mu$ l, platelet count $>300 \times 10^{3} / \mu$ l, abnormal corrected plasmatic calcium level, and lactate dehydrogenase (LDH) >1.5 times the upper limit of normal) criteria that should be tuned by tumor molecular features [4]. The molecules HIF1 $\alpha$, VEGF, VEGFR2, CAIX, all involved in the signaling cascade expression, have been tested in pretherapy tumor samples, but their expression has failed to predict a therapeutic response in patients submitted to antiangiogenic treatment [4]. Only the high HIF $2 \alpha$ expression (assessed by Western blot) has been reported to be associated with sunitinib response in a small cohort of 43 patients, and the plasmatic levels of soluble forms of VEGFR2 and VEGFR3 upon initiation or during the first weeks of systemic treatment have also been proposed to be predictive of therapeutic response [4]. These results should be confirmed by further studies, and the current clinical trials aim to identify and/or validate such predictive biomarkers. Regarding VHL gene status (inactivated by mutation or methylation vs. wild type), complex results have been reported. Choueiri et al. [26] found no association between VHL status and response rates or median progression-free survival, but the presence of 'loss-offunction' mutations was an independent factor associated with improved response. Moreover, VHL gene status could be relevant for patients treated with sorafenib and bevacizumab and not for patients treated with sunitinib and the new tested inhibitors axitinib or pazopanib [4, 27]. These differences could underlie non-VHL-related antitumor effects of sunitinib, axitinib, and pazopanib, or they could be explained by a variable drug sensitivity of the VHL/HIF/VEGF pathway in VHL wild-type RCC. Overall, these data support the need for further studies investigating the relationships between VHL gene status and the antiangiogenic therapeutic response.

As has already been mentioned, the clinical effects of antiangiogenic drugs in patients with papillary RCC seem to be limited [6]. It is important to note that fumarate hydratase activity (which is decreased significantly in papillary RCC) is related in part to the HIF pathway; FH inhibition leads to elevated intracellular fumarate which in turn acts as a competitive inhibitor of HPH (HIF prolyl hydroxylase), thereby causing stabilization of HIF by preventing proteasomal degradation [28-30]. An elevated HIF drives the transcription of key components of the glycolytic pathway, including GLUT1 and LDH, inducing the Warburg effect (the tendency of cancer cells to rely on glycolysis as their energy source). However, there are probably other tumor suppressor roles of $\mathrm{FH}$ that are probably HIF independent and involve, in particular, the DNA damage response [31].

\section{mTOR Pathway}

The PI3K-AKT-mTOR cascade appears to be another pivotal pathway in clear cell RCC but also in non-clear cell RCC. Upon the binding of ligands on membrane growth factor and/or cytokine receptors, the phosphoinositide 3 kinase generates PIP3 and activates AKT. PTEN is a phosphatase that promotes the generation of PIP2 from PIP3, negatively regulating the cascade. The phosphorylated AKT activates mTOR complex 1 (mTORC1) through inhibition of TSC1/TSC2, and mTORC1 activates protein synthesis through phosphorylation of key regulators such as the P70 S6 kinase (S6) [32]. Activated phosphorylated S6 (phospho-S6) exerts a negative feedback loop on IRS1/IRS2 receptors upstream to PI3K. It is important to note that the targets of S6 include factor HIF1 $\alpha$; this explains why HIF1 $\alpha$ expression is dependent on mTOR and sensitive to rapamycin or rapalogues such as temsirolimus and everolimus. This effect could account at least partially for the activity of mTOR inhibitors in kidney cancer. Phase III trials have shown that temsirolimus improves overall survival in patients with advanced RCC and poor prognostic features, and everolimus improves progression-free survival in patients for which sorafenib and/or sunitinib has become ineffective, in both clear cell and non-clear cell RCC [7, 33-35]. Furthermore, as signaling downstream to VEGFR involves the PI3K-AKT-mTOR pathway, the mTOR inhibitors might theoretically affect both tumor cells and tumor-associated endothelial cells. Pantuck et al. [36] studied the activated status of the MTOR pathway using phospho-S6 as a marker for this activation. Phospho-S6 was associated with tumor stage, grade, and disease-specific survival in patients with localized or meta- 
static disease. A small retrospective analysis has suggested that high expression of phospho-AKT or phospho-S6 could be associated with the response to temsirolimus [37]. The value of these biomarkers and other candidates within the PI3K-AKT-mTOR pathway must be validated in larger retrospective and prospective studies. PTEN expression does not seem to have any predictive value in that context [38].

Besides mTORC1, mTORC2 is another mTOR complex in the pathway with the ability to activate AKT through phosphorylation. There is some evidence that HIF1 $\alpha$ expression is dependent on both mTORC1 and mTORC2 and that HIF $2 \alpha$ expression is dependent only on mTORC2 [39]. As temsirolimus and everolimus are only active on mTORC1, HIF $2 \alpha$ is not targeted by these therapies, providing an explanation for the resistance to mTORC1 inhibitors. Furthermore, the action of mTORC1 inhibitors on S6 results in the loss of feedback inhibition and AKT phosphorylation through mTORC2 [32]. These considerations underscore the importance of targeting mTORC2 (inhibitors targeting both MTORC1 and mTORC2 are under investigation) and probably of combining treatment with new inhibitors of IRS1/IRS2 or PI3K.

The mTOR inhibitors could be of interest for treating metastatic chromophobe cell carcinoma, but the data are still limited [7]. It is interesting that mouse models deficient for the FLCN gene have been generated, developing oncocytic cysts and renal tumors and mimicking BirtHogg-Dubé (BHD) syndrome which predisposes subjects to develop renal carcinomas of nearly all subtypes (the chromophobe cell RCC subtype being the most frequent in BHD nevertheless) [40-43]. The tumor suppressor role of FLCN has been demonstrated, but contradictory results regarding the role of FLCN in the PI3K-AKT-mTOR pathway have been described, with the mTOR target phospho-S6 being increased or decreased depending on the context and/or the model. Additional studies are mandatory before considering that inhibitors of both mTORC1 and mTORC2 might be effective as potential therapeutic agents for BHD-associated kidney cancer.

\section{Myc Pathway}

A c-MYC gain (8q24) has been observed in up to $20 \%$ of clear cell RCC via either genome-wide or specific FISH analysis, and it has been correlated with concomitant overexpression suggesting its involvement in renal oncogenesis $[14,44]$. Moreover, pathway analysis and experi-

Kidney Cancer Pathology in the

Context of Targeted Therapy ments in cell lines support activation of the c-MYC pathway, resulting in cell cycle promotion [13]. Recently, a study elegantly demonstrated that HIF $\alpha$ effects on c-myc could distinguish 2 subtypes of sporadic VHL-deficient clear cell renal carcinoma: the fraction of VHL-deficient clear cell RCC with coexpressed HIF $1 \alpha$ and HIF $2 \alpha$ could activate the AKT/mTOR and ERK/MAPK pathways and be likely to respond to antiangiogenic and $\mathrm{mTOR}$ inhibitors, and the fraction of VHL-deficient clear cell RCC with HIF $2 \alpha$ expressed alone could promote myc transcriptional activity, with higher rates of cell proliferation and tumor growth [45]. The authors suggest that this molecular stratification according to the HIF $1 \alpha / \mathrm{HIF} 2 \alpha$ expression could provide a framework for subclassifying tumors for targeted therapy. The pertinence of these 2 subtypes of clear cell RCC with regard to the therapeutic response to $\mathrm{mTOR}$ inhibitors or antiangiogenics remains to be tested. Furthermore, high-grade papillary renal cell carcinoma (type 2) has also been shown to be associated with the c-MYC signature [46]. This signature was correlated with the gain of chromosome $8 \mathrm{q}$ and overexpression of c-MYC located in 8q24. Overall, these observations raise a potential interest in future therapy targeting the c-MYC pathway in a fraction of clear cell and highgrade papillary RCC using the MYC inhibitor or siRNA strategy, for instance.

\section{c-MET Pathway}

Activating mutations in the tyrosine kinase domain of the $c$-MET gene $(7 \mathrm{q} 31)$ have been detected in the germ line of affected individuals in the hereditary papillary RCC (HRPC) kindred and in tumors from patients with sporadic type 1 papillary RCC. c-MET is the receptor for the hepatocyte growth factor (HGF) (7q21.1), and the HGF/cMET signaling pathway is involved in proliferation, survival, cell growth, differentiation, and cell migration. The involvement of the HGF/c-MET pathway in papillary RCC oncogenesis is supported by the frequent trisomy of chromosome 7 observed in sporadic type 1 papillary RCC, but the modest rate of $c-M E T$ mutation (13\%) could suggest that other major pathways are to be investigated in sporadic papillary RCC. Most inherited cases are lowgrade tumors occurring rather in the 5 th decade. However, an early-onset HPRC phenotype has been described, including metastasis progression [47]. Likewise, most sporadic type 1 papillary RCC are associated with a favorable outcome, but a recent study reported on metastatic type 1 papillary RCC with outcomes even worse than

Pathobiology 2011;78:90-98 
those for metastatic type 2 RCC [48]. Such metastatic type 1 papillary RCC are good candidates for treatment with drugs targeting the c-MET pathway according to different strategies, antagonism of ligand/receptor interaction, inhibition of tyrosine kinase catalytic activity, and blockade of receptor/effector interactions [49]. Such options are currently being investigated in clinical trials. The c-MET receptor could belong to the 'dependence receptor' family, and blockade of the pathway is expected to promote apoptosis in tumor cells [50]. Furthermore, a recent screen detected c-MET as a kinase required for survival in VHLdefective renal cancer cells, prompting an interest in targeting the c-MET pathway also in clear cell RCC [51]. Cooperation between $\mathrm{FH}$ and c-MET in transformation and tumorigenesis was also demonstrated in a cell line model, underscoring the way pathways can interplay and the potential interest in combined targeted therapy [52].

\section{Immune Response}

Immunotherapy aims to elicit an antitumor immune response resulting in significant disease remission. The most consistent antitumor activity has been reported with IFN- $\alpha$ and IL-2. The superiority of sunibitib, temsirolimus, and bevacizumab plus IFN- $\alpha$ over IFN- $\alpha$ alone has limited the role of single-agent IFN- $\alpha$. However, trials with high-dose intravenous bolus IL-2 have demonstrated a durable response in $7-8 \%$ patients, supporting the use of this cytokine therapy in some patients with metastatic RCC $[53,54]$. It is important to note that IL-2 is the only therapy for kidney cancer that can produce a remission of the disease that lasts after the treatment has been completed. According to published data, immunotherapy should be restricted to patients with metastatic RCC, good risk, and a clear cell subtype. Moreover, in clear cell RCC, additional predictive features of a better response to high-dose IL-2 could be an alveolar pattern $>50 \%$, no granular or papillary features, and expression of carbonic anhydrase IX (CAIX) in immunohistochemistry in $>85 \%$ of tumor cells [55]. Indeed, in one study the response rate was $59 \%$ for patients with a good risk and high CAIX expression versus less than $5 \%$ for patients in the poor-risk group with low CAIX expression [55]. A high-dose IL-2 trial is currently investigating its efficacy according to these predictive features to prospectively validate the selection criteria and to identify the patients likely to benefit the most from immunotherapy. A recent study based on a proteomic approach attempted to identify a new biomarker in the immunotherapy setting [56].

\section{Conclusion}

During the last 10 years, intense research in the renal cancer field has provided a huge amount of new molecular knowledge, supplying a rationale for targeted therapy in metastatic disease. Though no tissue biomarker can currently be recommended to predict therapeutic response, CAIX expression for high-dose IL-2 immunotherapy, VHL gene status, and HIF2 $\alpha$ expression for antiangiogenic drugs, as well as phosphorylated protein S6 expression for mTOR inhibitor use, are the leading candidates under investigation. Besides the tissue analysis in progress, other useful biomarker studies include clinical features, functional imaging, and blood investigations. Parallel to the emergence of targeted therapy, the classification of renal tumors has been defined both on a morphological and on a molecular basis, appearing more complex than 10 years ago, and the design of future clinical trials should take into account this variety of tumor subtypes to provide the most relevant conclusions. Meanwhile, the pathways involved in renal cancer are amazingly intermingled and shared at least partly by the different tumors subtypes, suggesting common oncogenetic determinants and the possibility of using the same drugs for different diseases. Future studies will investigate combination and sequential therapy, mechanisms of resistance, and their effects in adjuvant or neoadjuvant settings.

References carcinoma. Lancet 2009;373:1119-1132.

2 Motzer RJ, Bander NH, Nanus DM: Renalcell carcinoma. N Engl J Med 1996;335:865875.

3 Eble J, Sauter G, Epstein J, Seesterheen I (eds): World Health Organization Classification of Tumours. Pathology and Genetics of Tumours of the Urinary System and Male Genital Organs. Lyon, IARC Press, 2004.

-4 Atkins MB, Choueiri TK, Cho D, Regan M, Signoretti S: Treatment selection for patients with metastatic renal cell carcinoma. Cancer 2009; 115:2327-2333.

5 Jones J, Libermann TA: Genomics of renal cell cancer: the biology behind and the therapy ahead. Clin Cancer Res 2007;13:685s$692 \mathrm{~s}$.

6 Choueiri TK, Plantade A, Elson P, Negrier S, Ravaud A, Oudard S, et al: Efficacy of sunitinib and sorafenib in metastatic papillary and chromophobe renal cell carcinoma. J Clin Oncol 2008;26:127-131.
96

Pathobiology 2011;78:90-98
Allory/Culine/de la Taille 
7 Dutcher JP, de Souza P, McDermott D, Figlin RA, Berkenblit A, Thiele A, et al: Effect of temsirolimus versus interferon-alpha on outcome of patients with advanced renal cell carcinoma of different tumor histologies. Med Oncol 2009;26:202-209.

-8 Srigley JR, Delahunt B: Uncommon and recently described renal carcinomas. Mod Pathol 2009;22(suppl 2):S2-S23.

9 Klatte T, Pantuck AJ, Said JW, Seligon DB, Rao NP, LaRochelle JC, Shuch B, Zisman A, Kabbinavar F: Cytogenetic and molecular tumor profiling for type 1 and type 2 papillary renal cell carcinoma. Clin Cancer Res 2009; 15:1162-1169.

10 Cheng L, Zhang S, MacLennan GT, LopezBeltran A, Montironi R: Molecular and cytogenetic insights into the pathogenesis, classification, differential diagnosis, and prognosis of renal epithelial neoplasms. Hum Pathol 2009;40:10-29.

- 11 Young AC, Craven RA, Cohen D, Taylor C, Booth C, Harnden P, et al: Analysis of VHL gene alterations and their relationship to clinical parameters in sporadic conventional renal cell carcinoma. Clin Cancer Res 2009; 15:7582-7592.

12 Kaelin WG: The von Hippel-Lindau tumor suppressor protein and clear cell renal carcinoma. Clin Cancer Res 2007;13:680s-684s.

$\checkmark 13$ Furge KA, Tan MH, Dykema K, Kort E, Stadler W, Yao X, et al: Identification of deregulated oncogenic pathways in renal cell carcinoma: an integrated oncogenomic approach based on gene expression profiling. Oncogene 2007;26:1346-1350.

-14 Beroukhim R, Brunet J, Di Napoli A, Mertz KD, Seeley A, Pires MM, et al: Patterns of gene expression and copy-number alterations in von-Hippel Lindau disease-associated and sporadic clear cell carcinoma of the kidney. Cancer Res 2009;69:4674-4681.

$\checkmark 15$ Gad S, Lefèvre SH, Khoo SK, Giraud S, Vieillefond A, Vasiliu V, et al: Mutations in BHD and TP53 genes, but not in HNF1beta gene, in a large series of sporadic chromophobe renal cell carcinoma. Br J Cancer 2007;96:336-340.

16 Maxwell PH, Wiesener MS, Chang GW, Clifford SC, Vaux EC, Cockman ME, et al: The tumour suppressor protein VHL targets hypoxia-inducible factors for oxygen-dependent proteolysis. Nature 1999;399:271-275.

$\checkmark 17$ Maxwell PH: The HIF pathway in cancer. Semin Cell Dev Biol 2005; 16:523-530.

$\checkmark 18$ Smaldone MC, Maranchie JK: Clinical implications of hypoxia inducible factor in renal cell carcinoma. Urol Oncol 2009;27:238245.

19 Kaelin WG: Treatment of kidney cancer: insights provided by the VHL tumor-suppressor protein. Cancer 2009;115:2262-2272.
20 Yang JC, Haworth L, Sherry RM, Hwu P, Schwartzentruber DJ, Topalian SL, et al: A randomized trial of bevacizumab, an antivascular endothelial growth factor antibody, for metastatic renal cancer. N Engl J Med 2003;349:427-434.

21 Motzer RJ, Michaelson MD, Rosenberg J, Bukowski RM, Curti BD, George DJ, et al: Sunitinib efficacy against advanced renal cell carcinoma. J Urol 2007;178:1883-1887.

22 Motzer RJ, Hutson TE, Tomczak P, Michaelson MD, Bukowski RM, Rixe O, et al: Sunitinib versus interferon alfa in metastatic renal-cell carcinoma. N Engl J Med 2007;356: 115-124.

23 Escudier B, Eisen T, Stadler WM, Szczylik C, Oudard S, Staehler M, et al: Sorafenib for treatment of renal cell carcinoma: final efficacy and safety results of the phase III treatment approaches in renal cancer global evaluation trial. J Clin Oncol 2009;27:3312-3318.

24 Yang H, Minamishima YA, Yan Q, Schlisio $S$, Ebert BL, Zhang X, et al: pVHL acts as an adaptor to promote the inhibitory phosphorylation of the NF-kappaB agonist Card9 by CK2. Mol Cell 2007;28:15-27.

-25 Thoma CR, Toso A, Gutbrodt KL, Reggi SP, Frew IJ, Schraml P, et al: VHL loss causes spindle misorientation and chromosome instability. Nat Cell Biol 2009;11:994-1001.

26 Choueiri TK, Vaziri SAJ, Jaeger E, Elson P, Wood L, Bhalla IP, et al: von Hippel-Lindau gene status and response to vascular endothelial growth factor targeted therapy for metastatic clear cell renal cell carcinoma. J Urol 2008; 180:860-865.

27 Rini BI, Jaeger E, Weinberg V, Sein N, Chew $\mathrm{K}$, Fong $\mathrm{K}$, et al: Clinical response to therapy targeted at vascular endothelial growth factor in metastatic renal cell carcinoma: impact of patient characteristics and Von HippelLindau gene status. BJU Int 2006;98:756-762.

28 Isaacs JS, Jung YJ, Mole DR, Lee S, TorresCabala C, Chung Y, et al: HIF overexpression correlates with biallelic loss of fumarate hydratase in renal cancer: novel role of fumarate in regulation of HIF stability. Cancer Cell 2005;8:143-153.

29 Sudarshan S, Sourbier C, Kong H, Block K, Valera Romero VA, Yang Y, et al: Fumarate hydratase deficiency in renal cancer induces glycolytic addiction and hypoxia-inducible transcription factor 1alpha stabilization by glucose-dependent generation of reactive oxygen species. Mol Cell Biol 2009;29:40804090.

30 Pollard PJ, Brière JJ, Alam NA, Barwell J, Barclay E, Wortham NC, et al: Accumulation of Krebs cycle intermediates and overexpression of HIFlalpha in tumours which result from germline $\mathrm{FH}$ and $\mathrm{SDH}$ mutations. Hum Mol Genet 2005; 14:2231-2239.

- 31 Yogev O, Yogev O, Singer E, Shaulian E, Goldberg M, Fox TD, et al: Fumarase: a mitochondrial metabolic enzyme and a cytosolic/nuclear component of the DNA damage response. PLoS Biol 2010;8:e1000328.
32 Hudes GR: Targeting mTOR in renal cell carcinoma. Cancer 2009;115:2313-2320.

- 33 Motzer RJ, Escudier B, Oudard S, Hutson TE, Porta C, Bracarda S, et al: Efficacy of everolimus in advanced renal cell carcinoma: a double-blind, randomised, placebocontrolled phase III trial. Lancet 2008;372: 449-456.

34 Motzer RJ, Hudes GR, Curti BD, McDermott DF, Escudier BJ, Negrier S, et al: Phase I/II trial of temsirolimus combined with interferon alfa for advanced renal cell carcinoma. J Clin Oncol 2007;25:3958-3964.

35 Hudes G, Carducci M, Tomczak P, Dutcher J, Figlin R, Kapoor A, et al: Temsirolimus, interferon alfa, or both for advanced renal-cell carcinoma. N Engl J Med 2007;356:22712281.

- 36 Pantuck AJ, Seligson DB, Klatte T, Yu H, Leppert JT, Moore L, et al: Prognostic relevance of the mTOR pathway in renal cell carcinoma: implications for molecular patient selection for targeted therapy. Cancer 2007; 109:2257-2267.

-37 Cho D, Signoretti S, Dabora S, Regan M, Seeley A, Mariotti M, et al: Potential histologic and molecular predictors of response to temsirolimus in patients with advanced renal cell carcinoma. Clin Genitourin Cancer 2007;5:379-385.

38 Figlin RA, de Souza P, McDermott D, Dutcher JP, Berkenblit A, Thiele A, et al: Analysis of PTEN and HIF-1alpha and correlation with efficacy in patients with advanced renal cell carcinoma treated with temsirolimus versus interferon-alpha. Cancer 2009;115: 3651-3660.

39 Toschi A, Lee E, Gadir N, Ohh M, Foster DA: Differential dependence of hypoxia-inducible factors 1 alpha and 2 alpha on mTORC1 and mTORC2. J Biol Chem 2008;283:3449534499.

40 Chen J, Futami K, Petillo D, Peng J, Wang P, Knol J, et al: Deficiency of FLCN in mouse kidney led to development of polycystic kidneys and renal neoplasia. PLoS One 2008; 3:e3581.

-41 Hartman TR, Nicolas E, Klein-Szanto A, AlSaleem T, Cash TP, Simon MC, et al: The role of the Birt-Hogg-Dubé protein in mTOR activation and renal tumorigenesis. Oncogene 2009;28:1594-1604.

42 Hasumi Y, Baba M, Ajima R, Hasumi H, Valera VA, Klein ME, et al: Homozygous loss of BHD causes early embryonic lethality and kidney tumor development with activation of mTORC1 and mTORC2. Proc Natl Acad Sci USA 2009;106:18722-18727.

43 Hudon V, Sabourin S, Dydensborg AB, Kottis V, Ghazi A, Paquet M, et al: Renal tumour suppressor function of the Birt-Hogg-Dubé syndrome gene product folliculin. J Med Genet 2010;47:182-189. 
44 Yamaguchi S, Yoshihiro S, Matsuyama H, Nagao K, Fukunaga K, Matsumoto H, et al: The allelic loss of chromosome 3p25 with cmyc gain is related to the development of clear-cell renal cell carcinoma. Clin Genet 2003;63:184-191.

45 Gordan JD, Lal P, Dondeti VR, Letrero R, Parekh KN, Oquendo CE, et al: HIF-alpha effects on c-Myc distinguish two subtypes of sporadic VHL-deficient clear cell renal carcinoma. Cancer Cell 2008;14:435-446.

46 Furge KA, Chen J, Koeman J, Swiatek P, Dykema K, Lucin K, et al: Detection of DNA copy number changes and oncogenic signaling abnormalities from gene expression data reveals MYC activation in high-grade papillary renal cell carcinoma. Cancer Res 2007; 67:3171-3176

47 Schmidt LS, Nickerson ML, Angeloni D, Glenn GM, Walther MM, Albert PS, et al: Early onset hereditary papillary renal carcinoma: germline missense mutations in the tyrosine kinase domain of the met proto-oncogene. J Urol 2004;172:1256-1261.

48 Klatte T, Pantuck AJ, Said JW, Seligson DB, Rao NP, LaRochelle JC, et al: Cytogenetic and molecular tumor profiling for type 1 and type 2 papillary renal cell carcinoma. Clin Cancer Res 2009;15:1162-1169.
9 Bellon SF, Kaplan-Lefko P, Yang Y, Zhang Y, Moriguchi J, Rex K, et al: c-Met inhibitors with novel binding mode show activity against several hereditary papillary renal cell carcinoma-related mutations. J Biol Chem 2008;283:2675-2683.

50 Goldschneider D, Mehlen P: Dependence receptors: a new paradigm in cell signaling and cancer therapy. Oncogene 2010;29:18651882.

51 Bommi-Reddy A, Almeciga I, Sawyer J, Geisen C, Li W, Harlow E, et al: Kinase requirements in human cells. 3. Altered kinase requirements in VHL-/- cancer cells detected in a pilot synthetic lethal screen. Proc Natl Acad Sci USA 2008;105:16484-16489.

52 Costa B, Dettori D, Lorenzato A, Bardella C, Coltella N, Martino C, et al: Fumarase tumor suppressor gene and MET oncogene cooperate in upholding transformation and tumorigenesis. FASEB J 2010;24:2680-2688. DOI: 10.1096/fj.09-146928.

53 Fisher RI, Rosenberg SA, Fyfe G: Long-term survival update for high-dose recombinant interleukin-2 in patients with renal cell carcinoma. Cancer J Sci Am 2000;6:S55-S57.
54 McDermott DF, Regan MM, Clark JI, Flaherty LE, Weiss GR, Logan TF, et al: Randomized phase III trial of high-dose interleukin-2 versus subcutaneous interleukin-2 and interferon in patients with metastatic renal cell carcinoma. J Clin Oncol 2005;23: 133-141.

55 Atkins M, Regan M, McDermott D, Mier J, Stanbridge E, Youmans A, et al: Carbonic anhydrase IX expression predicts outcome of interleukin 2 therapy for renal cancer. Clin Cancer Res 2005;11:3714-3721.

56 Jones J, Otu HH, Grall F, Spentzos D, Can H, Aivado M, et al: Proteomic identification of interleukin-2 therapy response in metastatic renal cell cancer. J Urol $2008 ; 179: 730-736$.

57 Motzer RJ, Mazumdar M, Bacik J, Berg W, Amsterdam A, Ferrara J: Survival and prognostic stratification of 670 patients with advanced renal cell carcinoma. J Clin Oncol 1999; 17:2530-2540.

-58 Mekhail TM, Abou-Jawde RM, Boumerhi G, Malhi S, Wood L, Elson P, et al: Validation and extension of the Memorial Sloan-Kettering prognostic factors model for survival in patients with previously untreated metastatic renal cell carcinoma. J Clin Oncol 2005;23: 832-841. 